\title{
Audit Partner Tenure, Audit Firm Tenure, and Discretionary Accruals: Does Long Auditor Tenure Impair Earnings Quality?
}

\author{
Chih-Ying Chen ${ }^{*}$ \\ Department of Accounting \\ School of Business and Management \\ Hong Kong University of Science and Technology \\ Chan-Jane Lin \\ Department of Accounting \\ College of Management \\ National Taiwan University \\ Yu-Chen Lin \\ Department of Accounting \\ College of Management \\ National Cheng-Kung University
}

This version: June 2004

We thank Clive Lennox for providing comments.

* Corresponding author. Department of Accounting, School of Business and Management, Hong Kong University of Science and Technology, Clear Water Bay, Kowloon, Hong Kong. E-mail: accychen@ust.hk; Phone: (+852) 2358-7567; Fax: (+852) 2358-1693. 


\title{
Audit partner tenure, audit firm tenure, and discretionary accruals: Does long auditor tenure impair earnings quality?
}

\begin{abstract}
Audit partner rotation has been adopted in several countries, but the academic research has not investigated the relation between audit partner tenure and earnings quality. We investigate the relation using a sample of Taiwanese listed companies for which the audit report must show the audit partners’ names. We find a significantly negative relation between audit partner tenure and absolute discretionary accruals, a proxy for earnings quality. The negative relation mainly occurs after five to seven years of audit partner-client relationship. When audit firm tenure and audit partner tenure are analyzed simultaneously, audit firm tenure is not significantly related to absolute discretionary accruals but audit partner tenure is. Collectively, our evidence does not support the hypotheses that earnings quality decreases with audit partner tenure and that audit firm tenure decreases with earnings quality after controlling for audit partner tenure.
\end{abstract}

Keywords: Audit partner tenure; Audit firm tenure; Auditor rotation; Discretionary accruals 


\section{Introduction}

The recent accounting scandals across the world, from Enron and WorldCom in the U.S. to Parmalat in Europe, have raised public concerns about auditor independence. One factor the regulators are concerned that may impair auditor independence is long auditor tenure (the length of the auditor-client relationship). Their concern is that as the auditor tenure gets longer, auditors are more likely to compromise on their client's accounting and reporting choices in order to retain the client. The proponents of mandatory auditor rotation thus argue that setting a limit on the period of years an audit firm may audit a particular company’s financial statements will improve auditor independence and audit quality. The opponents, however, argue that as auditors gain more experience from auditing the same company over time, they have better knowledge to determine whether the company's accounting and reporting choices are proper. Their argument suggests an improvement in audit quality as the length of auditor tenure increases. The above arguments are not new because whether auditor rotation should be mandatory has been debated for many years. ${ }^{1}$

Several recent studies use accruals as a proxy for earnings quality and audit quality and empirically examine the relation between audit firm tenure and accruals. Johnson, Khurana, and Reynolds (2002) (hereafter JKR) find that relative to medium audit firm tenures of four to eight years, short audit firm tenures of two to three years are associated with larger absolute values of discretionary accruals. But they find no association between absolute discretionary accruals and longer audit firm tenures of nine or more years. Myers, Myers, and Omer (2003) (hereafter MMO) find that on average, the raw values and absolute values of discretionary accruals and current

\footnotetext{
${ }^{1}$ See Ng (2003) for some history of the concepts of mandatory auditor rotation. Myers, Myers, and Omer (2003) also describe the development of the concepts in the U.S.
} 
accruals decrease with audit firm tenure. Ghosh and Moon (2003) find a decrease in absolute discretionary accruals as the length of audit firm tenure increases. Collectively, the results in these studies do not support the argument that earnings quality deteriorates with extended audit firm tenure. $^{2}$

While mandatory rotation of audit firms is still under debates in some countries, periodic rotation of audit partners had been adopted before the recent accounting scandals. The professional requirements in the U.S. state that the partner in charge of an audit engagement should be replaced at least once every seven years. ${ }^{3}$ The Sarbanes-Oxley Act of 2002 further requires audit partner rotation at least once every five years. Several other countries also have a similar requirement. For example, audit partner rotation at least once every seven years is mandatory in Germany and is a professional requirement in the U.K. Despite the practice of audit partner rotation, however, the academic research has not investigated whether long audit partner tenure is associated with lower earnings quality. One possible reason is that audit reports in most countries do not show the audit partner's name and therefore the data of audit partner tenure are not available from public sources. In addition, when audit partner rotation is required, there will be no case of long audit partner tenure (e.g., longer than five or seven years), making it impossible to investigate the relation between long audit partner tenure and earnings quality.

In this paper, we investigate the relation between audit partner tenure, audit firm tenure, and earnings quality using a sample of Taiwanese listed companies. The regulation in Taiwan requires the audit report for public companies to be certified by two audit partners from the same audit firm,

\footnotetext{
2 Mansi, Maxwell, and Miller (2004) find a significantly negative relation between auditor tenure and the cost of corporate bonds.

${ }^{3}$ American Institute of Certified Public Accountants (AICPA), SEC Practice Section, Requirements of Members, item e.
} 
and the audit report must show the audit partners' names and the audit firm's name. ${ }^{4}$ This requirement makes it possible to determine audit partner tenure based on the information in audit reports. Audit partner rotation (at least once every five years) was not mandatory in Taiwan until 2003. Our sample period ends in 2001, so the sample includes the cases of long audit partner tenure and does not include the cases of audit partner change in response to the recent rotation requirement.

Following prior studies on the relation between audit firm tenure and earnings quality (JKR; MMO; Ghosh and Moon 2003), we use discretionary accruals as a proxy for earnings quality and investigate whether absolute discretionary accruals change with the length of audit partner tenure. Consistent with those studies, earnings that contain large magnitude of accruals are regarded as poor quality. We find that absolute discretionary accruals decrease with the length of audit partner tenure, and the decrease mainly occurs after five to seven years of audit partner-client relationship. These results do not suggest that earnings quality deteriorates with extended audit partner tenure. We also find that absolute discretionary accruals do not change significantly with audit firm tenure when audit partner tenure is controlled for. This finding suggests that when audit partner rotation is required, periodic rotation of audit firms may be unnecessary as the association between audit firm tenure and earnings quality is not significant.

Understanding the relation between audit partner tenure and earnings quality is important for audit firms when audit partner rotation is voluntary. Even if audit partner rotation is mandatory, audit firms may be interested in knowing how earnings quality changes with audit partner tenure

\footnotetext{
4 This requirement began in 1983. Before 1983, the audit reports had to be certified by one audit partner and had to show the partner's name and the audit firm's name.
} 
within the permitted length of tenure. ${ }^{5}$ Understanding the relation between audit partner tenure, audit firm tenure, and earnings quality is also important for the debate on whether audit firm rotation should be mandated. Periodic rotation of audit firms is more costly compared to periodic rotation of audit partners. If the two types of auditor rotation relate to earnings quality and audit quality in a similar way, it would be unwarranted to replace the current practice of audit partner rotation by audit firm rotation or to require audit firm rotation in addition to audit partner rotation.

The rest of the paper is organized as follows. The next section discusses the related studies and develops the hypotheses. Section 3 describes the research design and sample selection. Section 4 discusses the empirical results, and Section 5 provides conclusions.

\section{Related studies and hypotheses development}

Prior studies have used auditor litigation (Palmrose 1988), earnings response coefficients (Teoh and Wong 1993), accruals (Becker, DeFond, Jiambalvo, and Subramanyam 1998), and going-concern opinions (DeFond, Raghunandan, and Subramanyam 2002) as a proxy for audit quality. Recent studies investigating the relation between audit firm tenure and earnings/audit quality use discretionary accruals as a proxy for earnings/audit quality (JKR; MMO; Ghosh and Moon 2003). We follow a similar approach in this paper. Although other proxies such as going concern opinions and earnings restatements also have been used (e.g., Geiger and Raghunandan 2002; Myers, Myers, Palmrose, and Scholz 2003), the number of such cases is very small in our sample country. In this section, we first discuss the arguments and findings in the related studies. We then formulate our hypotheses based on those arguments and the observed practice of audit

\footnotetext{
${ }^{5}$ We note, however, that audit partners' behavior may be conditional on whether audit partner rotation is mandatory.
} 
partner rotation.

\section{Studies on auditor tenure and earnings quality}

A main purpose of audit work is to determine whether the financial report numbers fairly present the audited company's operating results and financial conditions. When audit quality is poor, the reported earnings numbers are more likely to contain items that obscure the "true" operating results and financial conditions. The quality of earnings thus reflects the quality of audit work. Since poor-quality earnings numbers are more likely to result in audit failures and auditor litigation, and large accruals are found to be positively associated with subsequent audit failures and auditor litigation (Geiger and Raghunandan 2002; Heninger 2001), it is plausible to use accruals as a proxy for earnings quality (and thus audit quality). Recent studies on the relation between audit firm tenure and earnings quality also provide similar arguments to support their use of accruals as a proxy for earnings quality.

JKR investigate the relation between audit firm tenure and absolute level of unexpected accruals, a proxy for earnings quality. ${ }^{6}$ The unexpected accruals are essentially the discretionary accruals estimated from a cross-sectional Jones (1991) model in the literature. They find that short audit firm tenures (two to three years) are associated with higher absolute levels of unexpected accruals. But they find no significant differences in the accruals of the clients with medium (four to eight years) or long (nine or more years) relationships with their auditor, suggesting that long audit firm tenures are not associated with a decline in earnings quality.

\footnotetext{
${ }^{6}$ JKR use the term "quality of financial reporting” instead of "earnings quality”, but we use the latter in this paper when citing their study.
} 
MMO investigate the relation between audit firm tenure and two measures of accruals: discretionary accruals and current accruals. They use the cross-sectional Jones (1991) model to estimate discretionary accruals, and their current accruals equal the change in non-cash current assets minus the change in current liabilities other than short-term debt. They find that the magnitude of both measures of accruals declines with longer audit firm tenure. They also find that longer audit firm tenure is associated with both less extreme income-increasing and less extreme income-decreasing accruals, which suggest that earnings management becomes more limited as audit firm tenure gets longer. Overall, MMO find no evidence that longer audit firm tenure is associated with lower earnings quality. Ghosh and Moon (2003) investigate the relation between audit firm tenure and absolute discretionary accruals and find results similar to MMO’s. Collectively, prior studies that use accruals to proxy for earnings quality find no evidence that earnings quality deteriorates with extended audit firm tenure.

In an independent and concurrent working paper, Chi and Huang (2003) investigate the relation between audit partner tenure, audit firm tenure and discretionary accruals using a sample of Taiwanese companies. They find that discretionary accruals initially are negatively related to audit partner tenure and audit firm tenure, suggesting the "learning effect” as auditor tenure gets longer. But the relations become positive after the tenure exceeds five years, suggesting lower earnings quality when the auditor is "excessively familiar" with the client. They also find that audit firm tenure is a more important factor than is audit partner tenure in explaining the relation between discretionary accruals and auditor tenure. ${ }^{7}$

\footnotetext{
7 The findings in Chi and Huang (2003) are different from ours. We compare the sample selection process and measurement of auditor tenure between the two studies in section 4 .
} 


\section{Development of hypotheses}

Proponents of mandatory audit firm rotation argue that audit quality is more likely to be compromised as the length of the auditor-client relationship increases. In contrast, opponents of mandatory audit firm rotation emphasize that lack of client-specific knowledge and experience for the new audit firm due to periodic rotation impairs audit quality. We think those arguments apply to the debates on audit partner rotation as well. In practice, the AICPA has a professional requirement for periodic audit partner rotation at least once every seven years. The SarbanesOxley Act of 2002 goes further to impose a limit of five years on audit partner tenure. The above requirements reflect the viewpoint that audit quality would deteriorate when audit partner tenure is “too long.” In light of this viewpoint, we formulate the following hypothesis:

\section{H1: Earnings quality decreases with audit partner tenure.}

Given that audit partner rotation has become a requirement and mandatory audit firm rotation is under consideration, ${ }^{8}$ it is important to know whether earnings quality would be further improved (or impaired) if a limit is imposed on audit firm tenure as well. Audit firm rotation is more costly compared to audit partner rotation. If longer audit firm tenure is not associated with lower earnings quality after controlling for audit partner tenure, further requiring audit firm rotation would be unwarranted. Even if longer audit firm tenure is associated with lower earnings quality, it is important to know whether the marginal improvement in earnings quality associated

\footnotetext{
8 While mandatory audit firm rotation was not included in the Sarbanes-Oxley Act of 2002, the U.S. Congress required the General Accounting Office (GAO) to study the potential effects of requiring rotation of the audit firms that audit public companies registered with the SEC. After conducting a study, the GAO concludes that mandatory audit firm rotation may not be the most efficient way to strengthen auditor independence and improve audit quality considering the additional financial costs and the loss of institutional knowledge of the public company's previous auditor of record, as well as the current reforms being implemented (GAO-04-216, November 2003).
} 
with shorter audit firm tenure is significant enough to justify the additional costs of mandatory audit firm rotation. Our second hypothesis is formulated as follows:

H2: Earnings quality decreases with audit firm tenure after controlling for audit partner tenure.

\section{Research design and sample selection}

\section{Measurement of audit partner tenure, audit firm tenure, and accruals}

As explained previously, the audit reports of public companies in Taiwan issued in or after 1983 must be certified by two audit partners and must show the audit partners' names in addition to the audit firm's name. We measure audit partner tenure based on two different definitions. The first one (denoted by APT1) is the length of tenure for the audit partner with longest tenure, where each partner's tenure equals the number of consecutive years the client has retained the audit partner. This is consistent with the Taiwanese regulators' perspective that both audit partners are regarded as engagement partners and rotation occurs only when both audit partners for the previous year are not retained. The second definition of audit partner tenure is the number of consecutive years the client has retained the same two audit partners (denoted by APT2). This definition assumes that when only one of the previous year's two audit partners is retained, the new partner relies more on his own knowledge and experience than on the retained partner's. ${ }^{9}$ There is no theory that provides

\footnotetext{
${ }^{9}$ If the two audit partners have different degree of involvement in the audit work (e.g., one is engagement partner and the other is concurring partner), audit partner tenure may be defined as the number of consecutive years the same person has been the engagement partner. We do not use this definition, however, because it is not possible to tell from the audit report whether there is indeed an engagement partner and, if there is, who is the engagement partner. The engagement partner's name does not always appear first in the audit report.
} 
guidance on which definition of audit partner tenure is more appropriate in our context. We think the above two definitions are both reasonable, and therefore we do the empirical analysis using both of them. Regarding audit firm tenure (denoted by AFT), we measure it as the number of consecutive years that the client has retained the audit firm. Continuation of audit firm tenure is assumed in case of audit firm merger. All measures of auditor tenure are counted beginning from 1983.

Following the arguments in prior studies on the relation between audit firm tenure and earnings quality, we use discretionary accruals as a proxy for earnings quality and investigate the relation between audit partner tenure, audit firm tenure, and absolute discretionary accruals. Because earnings can be managed either upward or downward depending on the manager's objectives, we assume large absolute discretionary accruals suggest poor earnings quality. This is also consistent with the studies where the direction of managers' incentives to engage in earnings management is not clear (Warfield, Wild, and Wild 1995; Klein 2002). Discretionary accruals (DA) are computed as follows:

$$
D A=T A-\left(\phi_{0}+\phi_{1}(\triangle S A L E S-\triangle A R)+\phi_{2} P P E\right),
$$

where $T A$ is total accruals (earnings before extraordinary items minus cash flows from operations), $\triangle S A L E S$ is change in net sales, $\triangle A R$ is change in net accounts receivable, and $P P E$ is net property, plant, and equipment. Firm and year subscripts are omitted for simplicity. The coefficients $\phi_{0}, \phi_{1}$, and $\phi_{2}$ are the parameters from estimating the following cross-sectional version of the modified Jones (1991) model:

$$
T A=\phi_{0}+\phi_{1}(\triangle S A L E S-\triangle A R)+\phi_{2} P P E+\varepsilon .
$$


All the variables and constant terms in (1) and (2) are scaled by beginning book value of total assets. Equation (2) is estimated by industry-year, consistent with DeFond and Jiambalvo (1994).

Kothari, Leone, and Wasley (2002) examine the specification and power of tests based on performance- matched discretionary accruals, and make comparisons with tests using traditional discretionary accrual measures (e.g., Jones and modified-Jones models). They find that performance-matched discretionary accrual measures enhance the reliability of inferences from earnings management research. Therefore, we also investigate the relation between auditor tenure and performance- matched discretionary accruals. We match each company-year observation with another from the same industry-year with the closest return on assets (ROA), where ROA equals income before extraordinary items divided by beginning book value of total assets. Performance-matched discretionary accruals (denoted by $P M D A$ ) equal $D A$ of the sample observation minus $D A$ of the matched observation, where $D A$ is discretionary accruals as defined previously. Hereafter, the term "discretionary accruals" refers to both $D A$ and PMDA unless indicated otherwise.

\section{Methods of empirical tests}

We first examine the unconditional relation between absolute discretionary accruals and audit partner tenure. Then we examine the relation after controlling for auditor type (Big-5 or non-Big-5) and the company's age, size, leverage, growth, and cash flow from operations. ${ }^{10}$ Prior studies have found those factors to be related to accruals (e.g., JKR; MMO; Becker, DeFond, Jiambalvo, and Subramanyam 1998; Francis and Krishnan 1999). We estimate the following

\footnotetext{
${ }^{10}$ We use the term "Big-5" to refer to the major audit firms, although the number of major audit firms changed from six to five during our sample period.
} 
equation to test H1:

$$
\begin{aligned}
\mid \text { Accruals } \mid=\beta_{0} & +\beta_{1} A P T+\beta_{2} \text { BIG5 }+\beta_{3} A G E+\beta_{4} S I Z E+\beta_{5} L E V+\beta_{6} G R O W+\beta_{7} C F O \\
& +\gamma \cdot \text { Industry }+\varepsilon,
\end{aligned}
$$

where Accruals is either $D A$ or $P M D A$, and $A P T$ is audit partner tenure (either $A P T 1$ or $A P T 2$, as defined previously). Regarding the control variables, BIG5 is a dummy variable equal to one if the audit partners are from a Big-5 audit firm and equal to zero otherwise, and $A G E$ is the number of years since the company was established. Firm size (SIZE) equals natural logarithm of total assets at year-end, leverage ( $L E V)$ equals total debt divided by total assets at year-end, growth (GROW) equals growth rate of total assets over the previous year, and $C F O$ equals net cash flow from operations scaled by beginning total assets. The equation also includes Industry, a set of dummy variables representing the company's industry. ${ }^{11}$

To test H2, we add audit firm tenure to equation (3) and test whether its coefficient is significantly different from zero. Specifically, we estimate the following equation to test whether audit firm tenure is related to absolute discretionary accruals after controlling for audit partner tenure:

$$
\begin{aligned}
\mid \text { Accruals } \mid= & \beta_{0}+\beta_{1} A P T+\beta_{2} A F T+\beta_{3} B I G 5+\beta_{4} A G E+\beta_{5} S I Z E+\beta_{6} L E V+\beta_{7} G R O W \\
& +\beta_{8} C F O+\gamma \cdot \text { Industry }+\varepsilon,
\end{aligned}
$$

where all the variables are as defined previously.

\footnotetext{
11 The Taiwan Stock Exchange assigns a four-digit code to each listed company, where the first two digits represent the industry classification code. We follow the same classification.
} 


\section{Sample selection}

The sample selection process is summarized in Table 1 . The initial sample includes all of the non-financial companies listed on the Taiwan Stock Exchange during 1990-2001. The sample period starts in 1990 because before that companies were not required to prepare statement of cash flows. Accounting data, audit firm’s name, and audit partners’ names are obtained from the Taiwan Economic Journal database. There are 3,665 company-years with all the required data available. We delete 382 observations of initial public offerings (IPOs), as prior studies find that companies report positive discretionary accruals before IPO and these accruals reverse following IPO (e.g., Teoh, Wong, and Rao 1998). We also delete 180 outliers which have TA, ( $\triangle S A L E S-\triangle A R)$, or $P P E$ at the top or bottom one percentile of the sample. As a result, there are 3,103 observations remaining.

The final sample depends on the definition of audit partner tenure. For APT1 (APT2), we delete 172 (723) observations with first year of audit partner tenure or audit firm tenure, and also delete 131 (471) observations that are in the last year with the predecessor audit partners or audit firm. These deletions are generally consistent with JKR and MMO. ${ }^{12}$ Lastly, we require a minimum of eight companies in the industry-year to estimate $D A$, which results in deletion of 145 (173) observations for the analysis of APT1 (APT2). The final sample consists of 2,655 $(1,736)$ company-years when audit partner tenure equals APT1 (APT2). For the rest of the paper, those 2,655 (1,736) observations are referred to as Sample 1 (Sample 2). The number of observations in

\footnotetext{
12 MMO delete the observations that are in the last year with the predecessor audit firm in their sensitivity analysis but not in the primary analysis.
} 
each year for Sample 1 (Sample 2) ranges from 100 to 379 (from 56 to 299). ${ }^{13}$

\section{Empirical results}

\section{Descriptive statistics}

Table 2 presents descriptive statistics of the variables. For audit firm tenure (AFT), the median is 10 years and the mean is around 10 years for both samples. The mean of APT1 (APT2) is 8.43 (5.39) years, and the median of APT1 (APT2) is 8 (5) years. It is natural to have APT1 greater than APT2 because, according to the definition of APT1 (APT2), an observation's audit partner tenure continues (discontinues) when only one of the two audit partners for the previous year is retained in the current year. For Sample 1, the mean and median of PMDA are closer to zero than are the mean and median of $D A$. This result is consistent with the summary statistics in Kothari, Leone, and Wasley (2002). It is also an anticipated result because when company A is matched with company B, more likely than not B would be matched with A, in which case the mean of the two companies' PMDA equals zero. The mean and median of $|D A|$ equals 5.34 percent and 3.70 percent of beginning total assets, respectively. The mean and median of $|P M D A|$ equals 7.30 percent and 5.43 percent of beginning total assets, respectively. The skewed distribution of $|D A|$ and $|P M D A|$ comes from the approximately symmetric distribution of $D A$ and $P M D A$, respectively. About 76 percent of the sample is audited by a Big- 5 audit firm. This percentage is close to the market share of the Big-5 audit firms in Taiwan. Except for GROW, the other control variables all have a symmetric distribution. Sample 2 consists of about 65 percent of the observations in Sample

\footnotetext{
13 Our sample does not include start-up companies because one requirement to be listed on the Taiwan Stock Exchange is at least five years of operations.
} 
1, but the descriptive statistics of the variables are very close between the two samples except for audit partner tenure where by definition APT2 would not exceed APT1. The large difference between $A P T 1$ and $A P T 2$ suggests that most cases of audit partner change involve change of only one audit partner.

\section{Univariate analysis}

We first compute $|D A|$ and $|P M D A|$ by audit partner tenure and show the results in Figure 1. Panel A shows that for Sample 1, $|D A|$ and $|P M D A|$ are larger in earlier years than in later years of audit partner tenure, and $|D A|(|P M D A|)$ is largest when the length of the tenure equals six (four) years. A similar pattern appears in Panel B, for Sample 2, and $|D A|(|P M D A|)$ is largest when the length of the tenure equals five (eight) years. ${ }^{14}$ Because the number of observations is smaller for later years of tenure (especially when the tenure exceeds 15 years), we also compute $|D A|$ and $|P M D A|$ by portfolio ranking of audit partner tenure. We construct seven portfolios each year on audit partner tenure and find results (not shown) similar to the pattern in Figure $1 .{ }^{15}$ The absolute discretionary accruals are larger for the portfolios with relatively short tenure, and the portfolio with the largest $|D A|$ and $|P M D A|$ has audit partner tenure ranging from five to eight years.

We also compare the difference in absolute discretionary accruals between the short-tenure group $(A P T \leq N)$ and the long-tenure group $(A P T>N)$, where $N=5$ or 7 years, the limit of the length of audit partner-client relationship imposed by the countries that require audit partner

\footnotetext{
14 Panel B does not include APT2 = 17 and 18 because they have only one observation.

15 We are unable to construct more than seven equal-size portfolios because the length of auditor tenure ranges from two to eight years for the first sample year. Recall that auditor tenure is counted starting from 1983, the sample period starts from 1990, and the observations with first year of auditor tenure are deleted. The portfolios are not of equal size for the early sample years.
} 
rotation. As shown in Table 3, the means and medians of $|D A|$ and $|P M D A|$ are always larger for the short-tenure group regardless of the measure of audit partner tenure and the cut-off point for the length of tenure. The difference in the absolute discretionary accruals between the short-tenure and the long-tenure groups is significant at least at the 10 percent level except for the comparison of median $|P M D A|$ when the cut-off point is five years (in the last column). Collectively, Table 3 does not provide evidence that absolute discretionary accruals are larger when audit partner tenure is longer, consistent with the results illustrated in Figure 1.

\section{Multivariate analysis of the relation between absolute discretionary accruals and audit partner tenure}

Table 4 shows the regression results for equation (3). We estimate the equation for each year from 1990 to 2001. The reported coefficients are the means of yearly estimates, and the $t$-values equal the mean coefficient divided by standard error of yearly estimates (Fama and MacBeth 1973). Panel A shows that when $|D A|$ is the dependent variable, the mean coefficient on APT1 equals -0.0009 ( $t$-value $=-2.49)$. The significant coefficient suggests that an additional year of audit partner tenure (at least one of the two audit partners for the previous year continues to audit the company) is associated with an average decrease in absolute discretionary accruals of 0.09 percent of beginning total assets. This association is strong given the mean (median) APT1 of 8.43 (8.00) years and the mean (median) $|D A|$ of 5.34 (3.70) percent of beginning total assets reported in Table 2. The mean coefficient on auditor type (Big5) is significantly positive. This result is not consistent with higher audit quality of Big-5 audit firms. However, as discussed below, the coefficient on Big5 becomes insignificant when APT for the Big-5 auditors' clients is separated from APT for the non-Big-5 auditors' clients. The mean coefficients on the company's age and 
cash flow from operations are both significantly negative, consistent with the findings in JKR and MMO. The mean coefficient on growth in total assets is significantly positive, consistent with the finding in Ghosh and Moon (2003). The mean coefficients on company size and leverage are not significant.

Panel A also shows that when $|P M D A|$ is the dependent variable, the mean coefficient on APT1 equals $-0.0013(t$-value $=-2.39)$, which suggests that an additional year of audit partner tenure is associated with lower absolute discretionary accruals of 0.13 percent of beginning total assets when compared to the company in the same industry with a similar level of operating performance. The results for the control variables are similar between the two columns in Panel A except that the coefficient on Big5 is insignificant when $|P M D A|$ is the dependent variable.

Table 4, Panel B, shows that the mean coefficient on APT2 equals -0.0009 ( $\mathrm{t}$-value $=-2.31$ ) when $|D A|$ is the dependent variable, and equals -0.0014 (t-value $=-4.04$ ) when $|P M D A|$ is the dependent variable. The coefficient on Big5 is insignificant in both columns, and the results for other control variables are similar to the results in Panel A. In summary, the results in Table 4 do not support the first hypothesis that earnings quality decreases with audit partner tenure. Indeed, Table 4 shows evidence that earnings quality increases with audit partner tenure.

The model in equation (3) assumes a linear relation between absolute discretionary accruals and audit partner tenure. However, Figure 1 shows that the negative relation between absolute discretionary accruals and audit partner tenure mainly occurs when the length of the tenure exceeds certain "limit.” To allow for different relations between absolute discretionary accruals and audit partner tenure conditional on the length of the tenure, we run the following piecewise regressions: 


$$
\begin{aligned}
\mid \text { Accruals } \mid=\beta_{0} & +\beta_{1} A P T 5 Y+\beta_{2} A P T X 5 Y+\beta_{3} B I G 5+\beta_{4} A G E+\beta_{5} S I Z E+\beta_{6} L E V \\
& +\beta_{7} G R O W+\beta_{8} C F O+\gamma \cdot \text { Industry }+\varepsilon, \\
\mid \text { Accruals } \mid=\beta_{0} & +\beta_{1} A P T 7 Y+\beta_{2} A P T X 7 Y+\beta_{3} B I G 5+\beta_{4} A G E+\beta_{5} S I Z E+\beta_{6} L E V \\
& +\beta_{7} G R O W+\beta_{8} C F O+\gamma \cdot \text { Industry }+\varepsilon,
\end{aligned}
$$

where APT5Y (APT7Y) equals audit partner tenure up to five (seven) years and APTX5Y (APTX7Y) equals audit partner tenure in excess of five (seven) years. In other words, $A P T 5 Y=\min (A P T, 5)$, $A P T X 5 Y=A P T-A P T 5 Y, A P T 7 Y=\min (A P T, 7)$, and $A P T X 7 Y=A P T-A P T 7 Y$, where $A P T$ is either APT1 or APT2. All other variables are as defined previously. We use five years and seven years as the "limit" of audit partner tenure for the same reason as we indicate in the univariate analysis. It is important to know whether the relation between absolute discretionary accruals and audit partner tenure differs before and after the tenure reaches the limit. If the decrease in absolute discretionary accruals occurs before but not after the tenure reaches the limit, one might justify periodic rotation of audit partners by arguing that the rotation improves auditor independence in appearance (at certain costs) but does not impair audit quality. On the other hand, if the decrease in absolute accruals occurs only after the tenure reaches the limit, it would be more difficult to justify periodic rotation of audit partners by arguing that longer audit partner tenure impairs earnings quality.

Table 5 presents the results for estimating equations (5) and (6). To conserve space, we report only the coefficients on the variables for audit partner tenure. The unreported results for the control variables are all very similar to those reported in Table 4. The mean coefficients on audit partner tenure up to the limit ( $A P T 5 Y$ and $A P T 7 Y$ ) are all insignificant except in the regression of 
$|D A|$ on $A P T 2$ up to five years. In contrast, the mean coefficients on audit partner tenure in excess of the limit (APTX5Y and APTX7Y) are all significantly negative except in the regression of $|P M D A|$ on $A P T 1$ in excess of five years. Those results suggest that the negative relation between absolute discretionary accruals and audit partner tenure mainly occurs when the length of the tenure exceeds five or seven years. The significant coefficients on APTX5Y and APTX7Y are always more negative than the coefficients on $A P T$ reported in Table 4. This means the negative association between absolute discretionary accruals and long audit partner tenure is stronger than the results in Table 4 suggest. The coefficients on APTX5Y and APTX7Y are much more negative when $A P T$ equals $A P T 2$ than when $A P T$ equals $A P T 1$. This result suggests that the length of both audit partners' tenure matters in the relation to absolute discretionary accruals.

\section{The relation between absolute accruals and audit firm tenure after controlling for audit partner}

tenure

We estimate equation (4) to investigate whether audit firm tenure is related to absolute discretionary accruals after controlling for audit partner tenure. Although audit firm tenure is correlated with audit partner tenure, the diagnostics do not detect severe collinearity problem in estimating equation (4).$^{16}$ The regression results are presented in Table 6. Panel A shows that the coefficient on AFT is not significantly different from zero in both columns. While APT1 is significantly negatively related to $|D A|(t$-value $=-3.24)$, it is not significantly related to $|P M D A|$ $(t$-value $=-1.77, p$-value $=0.104$ in a two-tailed test). Panel B shows that $A F T$ is not significantly

\footnotetext{
16 The average correlation coefficient between AFT and APT1 (APT2) over the sample years equals 0.68 (0.36). The largest condition index (Belsley, Kuh, and Welsch 1980) for the regressions of equation (4) is 26.7, which is for year 1990 when AFT and APT1 are both in the equation. Most of the regressions have a condition index below 20.
} 
related to either $|D A|$ or $|P M D A|$, and $A P T 2$ is significantly negatively related to both $|D A|$ and $|P M D A| \cdot{ }^{17}$ The results for the control variables are unaffected when audit firm tenure is included in the regressions. Taken together, the results in Table 6 generally show that audit firm tenure is not related to absolute discretionary accruals but audit partner tenure is, so the evidence does not support H2. ${ }^{18}$

We also investigate whether the results in Table 6 are affected when the model allows for different relations between audit firm tenure and absolute discretionary accruals conditional on the length of tenure. Specifically, we decompose AFT in equation (5) (equation (6)) into two parts, audit firm tenure up to five (seven) years and audit firm tenure in excess of five (seven) years. The untabulated regression results indicate that the coefficient estimates for these two components of audit firm tenure are not significantly different from zero.

Our findings reported in Tables 4 and 6 are different from the findings in Chi and Huang (2003). However, the sample selection process and measurement of auditor tenure in their study are different from ours. Their sample period is only four years (1998-2001), while ours is 12 years. They do not delete IPOs and the observations that are either in the first year with a new audit firm or new audit partners or in the last year with the predecessor audit firm or audit partners, but we do. They trace the record of auditor tenure for up to ten years before the sample year, but we count auditor tenure beginning from 1983, the first year when the two audit partners' names must be

\footnotetext{
17 Note that the sum of the coefficients on APT and AFT indicates the change in absolute discretionary accruals associated with an additional year of audit by the same partner(s) from the same audit firm. In all columns of Table 6, the sum of the coefficients on $A P T$ and $A F T$ is significantly negative (t-value ranging from -1.83 to -2.57 ).

18 Unreported results show that when the regression equation includes audit firm tenure but not audit partner tenure, the coefficient on audit firm tenure is always negative. However, the coefficient is significant only for long tenure (e.g., in excess of seven years) and for the clients of the Big-5 audit firms.
} 
disclosed. ${ }^{19}$ The above differences make it difficult to compare the results between the two studies.

\section{Additional analyses}

Among the studies that investigate the relation between audit firm tenure and earnings quality, MMO delete the quick-turnover companies (i.e., the audit firm tenure lasts for less than five years), but JKR and Ghosh and Moon (2003) do not. MMO indicate that their results are not affected when their sample also includes the quick-turnover companies. In our primary analyses, we do not delete the quick-turnover companies because it is difficult to identify those companies precisely. For example, when the audit firm tenure or audit partner tenure has not lasted for five years as of the last sample year, it is not clear for how long the tenure will last. If those companies are deleted, the sample in the last few years will consist of only the companies with long auditor tenure (i.e., the auditor tenure has already lasted for at least five years). However, as an additional analysis, we delete the “confirmed” quick-turnover companies where the audit firm tenure or audit partner tenure had lasted for less than five years before an audit firm change or audit partner change took place during the sample period. The regression results (not shown) are similar to those reported in Tables 4-6 except that the coefficient on APT2 is not significant when $|P M D A|$ is the dependent variable.

Prior studies find that earnings reported by the clients of non-Big-N auditors contain relatively higher absolute discretionary accruals (e.g., Becker, DeFond, Jiambalvo, and Subramanyam 1998, where Big-N refers to Big-6). While we include a dummy variable BIG5 in

\footnotetext{
${ }^{19}$ We find that more than 30 percent of our sample observations for years 1998-2001 (the sample period in Chi and Huang (2003)) have audit partner tenure exceeding ten years, which suggests that a comparable portion of the sample in Chi and Huang (2003) has understated audit partner tenure.
} 
the regressions, we have not explored the (possibly) different relation between audit partner tenure and absolute discretionary accruals for the companies audited by different types of auditors. As an additional analysis, we separate auditor tenure of the Big-5 auditors' clients from auditor tenure of the non-Big-5 auditors' clients in the regression equations. Given our previous findings of negative relations between absolute discretionary accruals and audit partner tenure, we are interested in knowing whether the negative relations are attributable mainly to the Big-5 auditors' clients.

Tables 7 presents the regression results for the revised equation (3) in which the variable for audit partner tenure is separated into $A P T^{*} B i g 5$ and $A P T^{*} N o n B i g 5$, where Big5 (NonBig5) equals one if the audit partners are from a Big-5 (non-Big-5) audit firm and equals zero otherwise, and $A P T$ equals either $A P T 1$ or $A P T 2$. In Panel $\mathrm{A}$, the coefficient on $A P T 1 * B i g 5$ is significantly negative and the coefficient on $A P T 1 * N o n B i g 5$ is insignificant. When we further separate audit partner tenure into tenure up to five (or seven) years and tenure in excess of five (or seven) years, similar to the specification in equations (5) and (6), the coefficients (not shown) on those two components of audit partner tenure for the clients of non-Big-5 auditors remain insignificant. The above results reveal an association between longer audit partner tenure APT1 and lower absolute discretionary accruals only if the audit partners are from the Big-5 audit firms. The coefficient on Big5 is insignificant. The results for the other control variables are similar to those reported in Table 4.

In the first column of Panel B, the coefficient on $A P T 2 * B i g 5$ is insignificant $(t$-value $=-1.13)$ and the coefficient on $A P T 2 * N o n B i g 5$ is significantly negative ( $t$-value $=-3.77)$. In the second column of Panel B, the coefficients on APT2*Big5 and APT2*NonBig5 are both significantly negative. The results in those two columns seem to be inconsistent for the clients of the Big-5 
auditors. However, when we further separate APT2 into tenure up to $\mathrm{N}$ years and tenure in excess of $\mathrm{N}$ years ( $\mathrm{N}=5$ or 7 ), the coefficient (not shown) on APT2 up to $\mathrm{N}$ years is significantly positive and the coefficient on $A P T 2$ in excess of $\mathrm{N}$ years is significantly negative. Therefore, the results in Panel B reveal an association between longer audit partner tenure APT2 and lower absolute discretionary accruals if the audit partners are from the non-Big-5 audit firms, and if the partners are from the Big-5 audit firms and the tenure is sufficiently long.

In summary, we find that for the clients of the Big- 5 auditors, an additional year of audit by either one or both of the audit partners from the previous year is associated with lower absolute discretionary accruals. For the clients of the non-Big-5 auditors, an additional year of audit by the same two audit partners (instead of only one) from the previous year is associated with lower absolute discretionary accruals. The different results for the different client-groups suggest that audit partner changes are less likely to be associated with decreases in audit quality for the Big-5 audit firms than for the non-Big-5 audit firms. We interpret this finding as consistent with relatively higher audit quality of the Big-5 auditors.

\section{Conclusions}

While mandatory audit firm rotation is still under debate, prior studies have investigated the relation between audit firm tenure and earnings quality. Those studies find no evidence supporting the argument that earnings quality decreases with audit firm tenure. On the other hand, despite the requirement of periodic audit partner rotation in several countries for years, the academic research has not investigated the relation between audit partner tenure and earnings quality. In this paper, we ask two questions: (1) does earnings quality decrease with audit partner tenure, and (2) does 
earnings quality decrease with audit firm tenure after controlling for audit partner tenure. Our sample consists of Taiwanese listed companies for which the audit report must show the audit partners' names. In other countries, information about audit partners for a company is not available from public sources.

Consistent with prior studies, we use absolute discretionary accruals as a proxy for earnings quality. We find a significantly negative relation between absolute discretionary accruals and audit partner tenure, and the negative relation mainly occurs after five to seven years of the audit partner-client relationship. When audit firm tenure and audit partner tenure are analyzed simultaneously, audit firm tenure is not significantly related to absolute discretionary accruals but audit partner tenure is. Collectively, our results do not support the hypotheses that earnings quality decreases with audit partner tenure and that earnings quality decreases with audit firm tenure after controlling for audit partner tenure.

We note that as our sample consists of only Taiwanese companies during a time period when periodic audit partner rotation is not mandatory, our results may not generalize to the settings in other countries or the settings that require periodic audit partner rotation. Nevertheless, our study provides some inputs to the debates on auditor rotation. First, our evidence suggests that increased audit partner tenure is not associated with reduced earnings quality and audit quality. If the main argument for requiring audit partner rotation is to avoid deterioration in audit quality, then our evidence does not support the argument. Second, our evidence suggests that audit firm tenure is not more important than audit partner tenure in relation to earnings quality. Given that audit partner rotation has been adopted, if the main argument for further requiring audit firm rotation is to avoid deterioration in audit quality, then our evidence does not support the argument. Lastly, our 
finding of higher association with improved earnings quality when both audit partners are retained than when only one audit partner is retained for a longer period suggests that individual auditors' characteristics may have greater influence on audit quality than do audit firms' characteristics. 


\section{References}

Becker, C., M. DeFond, J. Jiambalvo, and K. Subramanyam. 1998. The effect of audit quality on earnings management. Contemporary Accounting Research 15 (Spring): 1-24.

Belsley, D., E. Kuh, and R. Welsch. 1980. Regression and Diagnostics. John Wiley \& Sons, Inc.

Chi, W., and H. Huang. 2003. Discretionary accruals, audit-firm tenure and audit-partner tenure: An empirical case in Taiwan. Working paper, National Chengchi University.

DeFond, M. L., and J. Jiambalvo. 1994. Debt covenant effects and the manipulation of accruals. Journal of Accounting and Economics 17 (January): 145-176.

DeFond, M. L., K. Raghunandan, and K. Subramanyam. 2002. Do nonaudit service fees impair auditor independence? Evidence from going concern audit opinions. Journal of Accounting Research 40: 1247-1274.

Fama, E. F., and J. D. MacBeth. 1973. Risk, return, and equilibrium: Empirical tests. Journal of Political Economy 71 (May/June), 607-636.

Francis, J. R., and J. Krishnan. 1999. Accounting accruals and auditor reporting conservatism. Contemporary Accounting Research 16 (Spring): 135-165.

Geiger, M., and K. Raghunandan. 2002. Auditor tenure and audit quality. Auditing: A Journal of Practice and Theory 21 (March): 187-196.

General Accounting Office Report November 2003. Public accounting firms: Required study on the potential effects of mandatory audit firm rotation (GAO-04-216).

Ghosh, A., and D. Moon. 2003. Does auditor tenure impair audit quality? Working paper, The Securities and Exchange Commission.

Heninger, W. G. 2001. The association between auditor litigation and abnormal accruals. The 
Accounting Review 76 (January): 111-126.

Johnson, V. E., I. K. Khurana, and J. K. Reynolds. 2002. Audit-firm tenure and the quality of financial reporting. Contemporary Accounting Research 19 (Winter): 637-660.

Jones, J. J. 1991. Earnings management during import relief investigations. Journal of Accounting Research 29 (Autumn): 193-228.

Klein, A. 2002. Audit committee, board of director characteristics, and earnings management. Journal of Accounting and Economics 33 (August): 375-400.

Kothari, S. P., A. J. Leone, and C. E. Wasley. 2002. Performance matched discretionary accrual measures. Working paper, Massachusetts Institute of Technology. (Forthcoming in Journal of Accounting and Economics, 2005).

Mansi, S. A., W. F. Maxwell, and D. P. Miller. 2004. Does auditor quality and tenure matter to investors? Evidence from the bond market. Journal of Accounting Research, forthcoming.

Myers, J. N., L. A. Myers, and T. C. Omer. 2003. Exploring the term of the auditor-client relationship and the quality of earnings: A case for mandatory auditor rotation? The Accounting Review 78 (July): 779-799.

Myers, J. N., L. A. Myers, Z.-V. Palmrose, and S. W. Scholz. 2003. Mandatory auditor rotation: Evidence from restatements. Working paper, University of Illinois.

Ng, C. 2003. Rotation of auditors: History and recent developments. Working paper, Griffith University.

Palmrose, Z.-V. 1988. An analysis of auditor litigation and audit service quality. The Accounting Review 63 (January): 55-73.

Teoh, S. H., and T. J. Wong. 1993. Perceived auditor quality and the earnings response coefficient. 
The Accounting Review 68 (April): 346-367.

Teoh, S. H., T. J. Wong, and G. Rao. 1998. Are accruals during initial public offerings opportunistic? Review of Accounting Studies 3: 175-208.

Warfield, T., J. Wild, and K. Wild. 1995. Managerial ownership, accounting choices, and informativeness of earnings. Journal of Accounting and Economics 20 (July): 61-91. 
Figure 1

Mean Absolute Discretionary Accruals by Audit Partner Tenure

Panel A: Mean absolute discretionary accruals by APT1

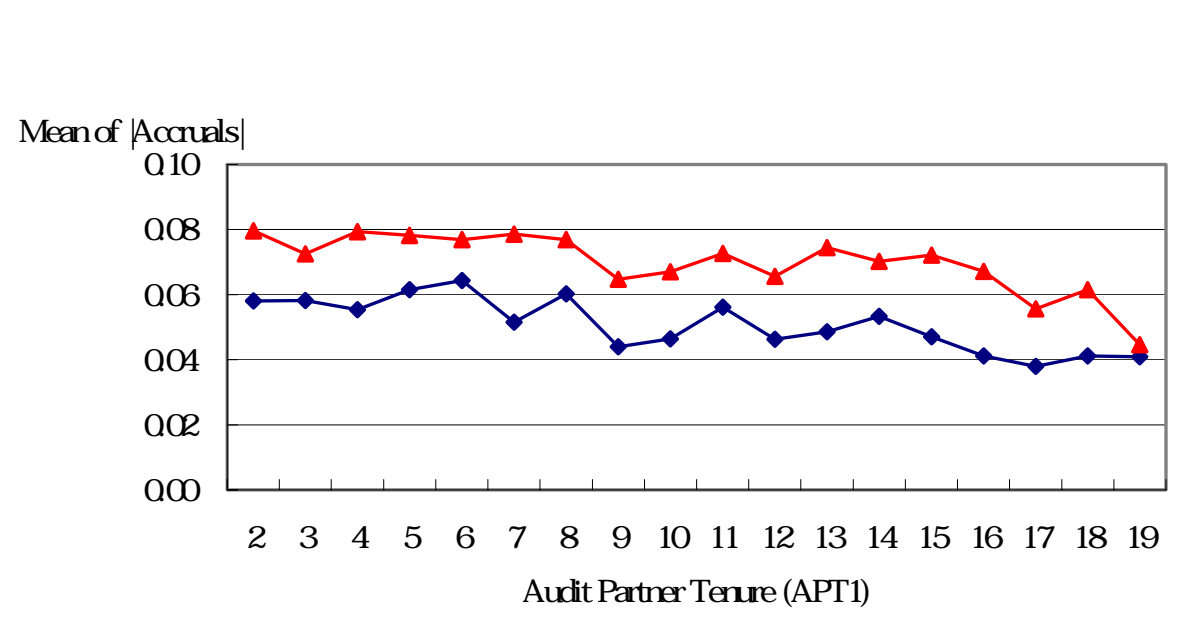

Panel B: Mean absolute discretionary accruals by APT2

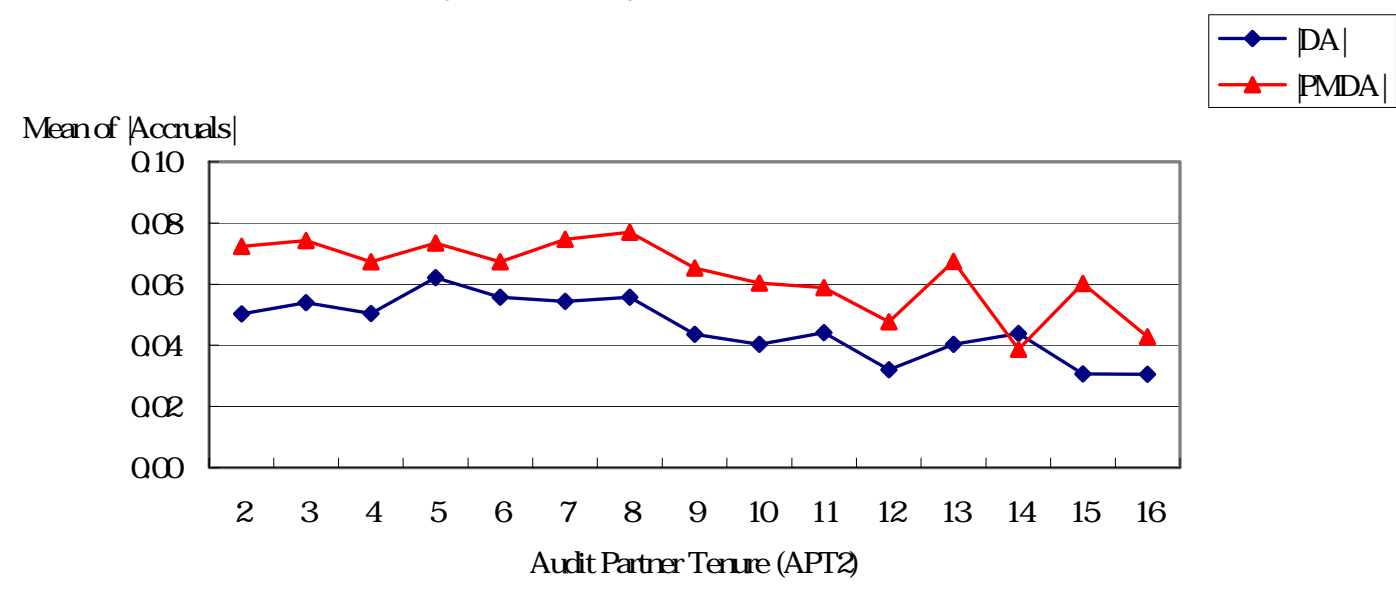

APT1 = Length of tenure for the audit partner with longest tenure, where each partner's tenure equals the number of consecutive years that the company has retained the audit partner

$A P T 2=$ Number of consecutive years that the company has retained the same two audit partners

$D A=$ Discretionary Accruals $=$ Total Accruals $-\left(\phi_{0}+\phi_{1}(\triangle S A L E S-\triangle A R)+\phi_{2} P P E\right)$, where Total Accruals equals earnings before extraordinary items minus cash flow from operations, $\triangle S A L E S$ is change in annual net sales, $\triangle A R$ is change in net accounts receivable, $P P E$ is net property, plant, and equipment, and $\phi_{\mathrm{j}}$ are parameters obtained from estimating the following equation by industry-year: Total Accruals $=\phi_{0}+\phi_{1}(\triangle S A L E S-\triangle A R)+\phi_{2} P P E+\varepsilon$. All variables and the constant terms are scaled by book value of beginning total assets.

$P M D A=$ Performance-matched discretionary accruals $=D A$ of the sample observation minus $D A$ of the company in the same industry-year with the closest ROA (earnings before extraordinary items divided by total assets). 
Table 1

\section{Sample Selection Process}

Number of observations of non-financial companies listed on the Taiwan Stock Exchange during 1990-2001

Less: Required accounting or auditor tenure data not available

Number of company-years with the required data

3,665

Less: IPOs

Less: Outliers ${ }^{\mathrm{a}}$

Number of observations remaining

Sample 1: Audit partner tenure equals length of tenure for the partner with longest tenure, where each partner's tenure equals the number of consecutive years that the company has retained the audit partner (APT1)

Number of observations excluding IPOs and outliers

Less: First year of audit partner tenure or audit firm tenure

Less: Last year of audit partner tenure or audit firm tenure

Less: Fewer than eight companies in the industry-year ${ }^{b}$

Number of observations for Sample 1

Sample 2: Audit partner tenure equals the number of consecutive years that the company has retained the same two audit partners (APT2)

Number of observations excluding IPOs and outliers

Less: First year of audit partner tenure or audit firm tenure

Less: Last year of audit partner tenure or audit firm tenure

Less: Fewer than eight companies in the industry-year ${ }^{\mathrm{b}}$

Number of observations for Sample 2

Notes:

${ }^{a}$ Defined as total accruals, change in net sales minus change in net accounts receivable, or net property, plant, and equipment (all scaled by beginning total assets) at top or bottom one percentile of the observations with available data. Those three variables are required to estimate discretionary accruals.

${ }^{\mathrm{b}}$ Require at least eight companies in the same industry-year to estimate the discretionary accruals. 
Table 2

\section{Descriptive Statistics}

\begin{tabular}{|c|c|c|c|c|c|}
\hline Variable & Mean & Std. Dev. & Q1 & Median & Q3 \\
\hline \multicolumn{6}{|c|}{ Sample $1(N=2,655):$} \\
\hline APT1 & 8.43 & 3.92 & 5.00 & 8.00 & 11.00 \\
\hline$A F T$ & 9.89 & 4.07 & 7.00 & 10.00 & 13.00 \\
\hline$D A(\%)$ & 0.30 & 7.63 & -3.63 & 0.11 & 3.78 \\
\hline$P M D A(\%)$ & -0.05 & 10.04 & -5.60 & 0.00 & 5.25 \\
\hline$|D A|(\%)$ & 5.34 & 5.45 & 1.69 & 3.70 & 6.99 \\
\hline$|P M D A|(\%)$ & 7.30 & 6.89 & 2.34 & 5.43 & 9.96 \\
\hline BIG5 & 0.76 & 0.43 & 1.00 & 1.00 & 1.00 \\
\hline$A G E$ & 26.36 & 9.84 & 19.00 & 26.00 & 33.00 \\
\hline SIZE & 1.90 & 1.03 & 1.18 & 1.80 & 2.47 \\
\hline$L E V$ & 0.24 & 0.16 & 0.11 & 0.23 & 0.34 \\
\hline GROW & 0.13 & 0.23 & -0.00 & 0.08 & 0.20 \\
\hline$C F O$ & 0.05 & 0.10 & 0.01 & 0.05 & 0.10 \\
\hline \multicolumn{6}{|c|}{ Sample $2(N=1,736):$} \\
\hline APT2 & 5.39 & 3.20 & 3.00 & 5.00 & 7.00 \\
\hline AFT & 10.12 & 4.05 & 7.00 & 10.00 & 13.00 \\
\hline$D A(\%)$ & 0.34 & 7.30 & -3.65 & 0.16 & 3.70 \\
\hline$P M D A(\%)$ & 0.12 & 9.52 & -5.09 & -0.01 & 5.29 \\
\hline$|D A|(\%)$ & 5.16 & 5.17 & 1.73 & 3.68 & 6.77 \\
\hline$|P M D A|(\%)$ & 6.99 & 6.46 & 2.32 & 5.17 & 9.58 \\
\hline BIG5 & 0.75 & 0.43 & 1.00 & 1.00 & 1.00 \\
\hline$A G E$ & 26.53 & 9.76 & 19.00 & 27.00 & 33.00 \\
\hline SIZE & 1.94 & 1.04 & 1.18 & 1.81 & 2.52 \\
\hline$L E V$ & 0.23 & 0.16 & 0.10 & 0.23 & 0.33 \\
\hline GROW & 0.13 & 0.22 & -0.00 & 0.08 & 0.21 \\
\hline $\mathrm{CFO}$ & 0.05 & 0.10 & 0.01 & 0.05 & 0.10 \\
\hline
\end{tabular}

Notes:

APT1 = Length of tenure for the audit partner with longest tenure, where each partner's tenure equals the number of consecutive years that the company has retained the audit partner

$A P T 2=$ Number of consecutive years that the company has retained the same two audit partners

AFT = Number of consecutive years that the company has retained the same audit firm

$D A=$ Discretionary accruals estimated based on the modified Jones model, as described in Figure 1

$P M D A=$ Performance-matched discretionary accruals, as described in Figure 1

BIG5 = 1 if the company's audit firm is one of the Big-5 audit firms; $=0$ otherwise

$A G E=$ Number of years since the company was established

SIZE = Natural logarithm of book value of total assets in billion dollars

$L E V=$ Total debt $/$ Total assets at year-end

GROW $=$ (Total assets at year-end)/(Total assets at the end of previous year $)-1$

$\mathrm{CFO}=$ Cash flow from operations scaled by beginning total assets 
Table 3

Comparison of Absolute Discretionary Accruals between the Short-Tenure and Long-Tenure Groups

\begin{tabular}{|c|c|c|c|c|c|}
\hline & $\mathrm{N}$ & Mean $|D A|$ & Median $|D A|$ & Mean $|P M D A|$ & Median $|P M D A|$ \\
\hline$A P T 1 \leq 5$ & 711 & 0.0587 & 0.0426 & 0.0774 & 0.0575 \\
\hline$A P T 1>5$ & 1,944 & 0.0515 & 0.0357 & 0.0713 & 0.0527 \\
\hline Difference & & 0.0072 & 0.0069 & 0.0061 & 0.0048 \\
\hline$t$-statistic & & $2.93^{* * *}$ & & $1.93^{*}$ & \\
\hline Z-statistic & & & $2.86^{* * *}$ & & 1.63 \\
\hline$A P T 1 \leq 7$ & 1,138 & 0.0582 & 0.0414 & 0.0776 & 0.0589 \\
\hline$A P T 1>7$ & 1,517 & 0.0498 & 0.0350 & 0.0695 & 0.0510 \\
\hline Difference & & 0.0084 & 0.0064 & 0.0081 & 0.0079 \\
\hline$t$-statistic & & $3.90^{* * *}$ & & $2.94^{* * *}$ & \\
\hline Z-statistic & & & $3.31^{* * *}$ & & $2.29^{* *}$ \\
\hline$A P T 2 \leq 5$ & 1,051 & 0.0535 & 0.0387 & 0.0721 & 0.0530 \\
\hline APT2 > 5 & 685 & 0.0487 & 0.0339 & 0.0666 & 0.0495 \\
\hline Difference & & 0.0048 & 0.0048 & 0.0055 & 0.0035 \\
\hline$t$-statistic & & $1.91^{*}$ & & $1.75^{*}$ & \\
\hline Z-statistic & & & $2.21^{* *}$ & & 0.74 \\
\hline$A P T 2 \leq 7$ & 1,319 & 0.0538 & 0.0386 & 0.0718 & 0.0539 \\
\hline$A P T 2>7$ & 417 & 0.0446 & 0.0310 & 0.0638 & 0.0467 \\
\hline Difference & & 0.0092 & 0.0076 & 0.0080 & 0.0072 \\
\hline$t$-statistic & & $3.40^{* * *}$ & & $2.32^{* *}$ & \\
\hline Z-statistic & & & $3.31^{* * *}$ & & $2.08^{* *}$ \\
\hline
\end{tabular}

Notes:

APT1 = Length of tenure for the audit partner with longest tenure, where each partner's tenure equals the number of consecutive years that the company has retained the audit partner

$A P T 2=$ Number of consecutive years that the company has retained the same two audit partners

$D A=$ Discretionary accruals, as described in Figure 1

$P M D A=$ Performance-matched discretionary accruals, as described in Figure 1

$* * *, * *$, and * indicate statistical significance at the $1 \%, 5 \%$, and $10 \%$ level, respectively (two-tailed). 
Table 4

\section{Regressions of Absolute Discretionary Accruals on Audit Partner Tenure and Control Variables}

\begin{tabular}{|c|c|c|c|c|}
\hline \multirow[b]{2}{*}{ Variable } & \multicolumn{2}{|c|}{ Panel A: $A P T=A P T 1$} & \multicolumn{2}{|c|}{ Panel B: $A P T=A P T 2$} \\
\hline & Accruals $=D A$ & Accruals $=$ PMDA & Accruals $=D A$ & Accruals $=$ PMDA \\
\hline Intercept & $\begin{array}{c}0.0818 \\
(6.27)^{* * *}\end{array}$ & $\begin{array}{c}0.1092 \\
(5.33)^{* * *}\end{array}$ & $\begin{array}{l}0.0808 \\
(3.89)^{* * *}\end{array}$ & $\begin{array}{c}0.1164 \\
(3.90)^{* * *}\end{array}$ \\
\hline$A P T$ & $\begin{array}{l}-0.0009 \\
(-2.49)^{* *}\end{array}$ & $\begin{array}{l}-0.0013 \\
(-2.39)^{* *}\end{array}$ & $\begin{array}{l}-0.0009 \\
(-2.31)^{* *}\end{array}$ & $\begin{array}{l}-0.0014 \\
(-4.04)^{* * *}\end{array}$ \\
\hline BIG5 & $\begin{array}{l}0.0025 \\
(2.43)^{* *}\end{array}$ & $\begin{array}{l}-0.0028 \\
(-0.82)\end{array}$ & $\begin{array}{c}-0.0003 \\
(-0.23)\end{array}$ & $\begin{array}{l}0.0014 \\
(0.40)\end{array}$ \\
\hline$A G E$ & $\begin{array}{l}-0.0006 \\
(-5.27)^{* * *}\end{array}$ & $\begin{array}{l}-0.0003 \\
(-2.17)^{*}\end{array}$ & $\begin{array}{l}-0.0005 \\
(-3.08)^{* * *}\end{array}$ & $\begin{array}{l}-0.0003 \\
(-1.50)\end{array}$ \\
\hline SIZE & $\begin{array}{l}-0.0006 \\
(-0.78)\end{array}$ & $\begin{array}{l}-0.0019 \\
(-1.53)\end{array}$ & $\begin{array}{c}-0.0010 \\
(-0.73)\end{array}$ & $\begin{array}{l}-0.0020 \\
(-1.01)\end{array}$ \\
\hline$L E V$ & $\begin{array}{l}0.0010 \\
(0.11)\end{array}$ & $\begin{array}{l}-0.0047 \\
(-0.49)\end{array}$ & $\begin{array}{l}0.0123 \\
(0.87)\end{array}$ & $\begin{array}{l}0.0015 \\
(0.11)\end{array}$ \\
\hline GROW & $\begin{array}{c}0.0259 \\
(3.07)^{* * *}\end{array}$ & $\begin{array}{c}0.0323 \\
(3.99)^{* * *}\end{array}$ & $\begin{array}{c}0.0361 \\
(4.91)^{* * *}\end{array}$ & $\begin{array}{c}0.0396 \\
(4.31)^{* * *}\end{array}$ \\
\hline CFO & $\begin{array}{l}-0.1397 \\
(-4.29)^{* * *}\end{array}$ & $\begin{array}{l}-0.0734 \\
(-2.87)^{* *}\end{array}$ & $\begin{array}{l}-0.1260 \\
(-3.54)^{* * *}\end{array}$ & $\begin{array}{l}-0.0797 \\
(-3.39)^{* * *}\end{array}$ \\
\hline Average adjusted $\mathrm{R}^{2}$ & 0.1648 & 0.1357 & 0.1818 & 0.1331 \\
\hline
\end{tabular}

Notes:

APT1 = Length of tenure for the audit partner with longest tenure, where each partner's tenure equals the number of consecutive years that the company has retained the audit partner

$A P T 2=$ Number of consecutive years that the company has retained the same two audit partners

$D A=$ Discretionary accruals, as described in Figure 1

$P M D A=$ Performance-matched discretionary accruals, as described in Figure 1

BIG5 = 1 if the company's audit firm is one of the Big-5 audit firms; $=0$ otherwise

$A G E=$ Number of years since the company was established

SIZE = Natural logarithm of book value of total assets in billion dollars

$L E V=$ Total debt $/$ Total assets at year-end

GROW $=$ (Total assets at year-end)/(Total assets at the end of previous year $)-1$

$\mathrm{CFO}=$ Cash flow from operations scaled by beginning total assets

The equation is estimated for each year from 1990 to 2001. The reported coefficients are the means of yearly estimates and the $t$-statistics (in parentheses) equal the mean coefficients divided by standard error of yearly estimates. The sample consists of 2,655 $(1,736)$ observations when APT equals APT1 (APT2). The mean coefficient estimates on the industry dummy variables are not reported. $* * *, * *$, and $*$ indicate statistical significance at the $1 \%, 5 \%$, and $10 \%$ level, respectively (two-tailed). 
Table 5

Regressions of Absolute Discretionary Accruals on Audit Partner Tenure Up to Five (or Seven) Years, Audit Partner Tenure in Excess of Five (or Seven) Years, and Control Variables

Eq. (5) $\mid$ Accruals $\mid=\beta_{0}+\beta_{1} A P T 5 Y+\beta_{2} A P T X 5 Y+\beta_{3} B I G 5+\beta_{4} A G E+\beta_{5} S I Z E+\beta_{6} L E V+\beta_{7} G R O W$

$$
+\beta_{8} C F O+\gamma \cdot \text { Industry }+\varepsilon
$$

Eq. (6) $\mid$ Accruals $\mid=\beta_{0}+\beta_{1} A P T 7 Y+\beta_{2} A P T X 7 Y+\beta_{3} B I G 5+\beta_{4} A G E+\beta_{5} S I Z E+\beta_{6} L E V+\beta_{7} G R O W$

$$
+\beta_{8} C F O+\gamma \cdot \text { Industry }+\varepsilon
$$

\begin{tabular}{|c|c|c|c|c|}
\hline \multirow[b]{2}{*}{ Variable } & \multicolumn{2}{|c|}{ Panel A: $A P T=A P T 1$} & \multicolumn{2}{|c|}{ Panel B: $A P T=A P T 2$} \\
\hline & Accruals $=D A$ & Accruals $=P M D A$ & Accruals $=D A$ & Accruals $=$ PMDA \\
\hline \multicolumn{5}{|l|}{ Eq. (5): } \\
\hline АРТ5Y & $\begin{array}{l}0.0005 \\
(0.38)\end{array}$ & $\begin{array}{c}-0.0018 \\
(-0.66)\end{array}$ & $\begin{array}{l}0.0026 \\
(2.24)^{* *}\end{array}$ & $\begin{array}{c}-0.0003 \\
(-0.35)\end{array}$ \\
\hline AРТX5Y & $\begin{array}{l}-0.0012 \\
(-1.86)^{*}\end{array}$ & $\begin{array}{c}-0.0008 \\
(-1.09)\end{array}$ & $\begin{array}{l}-0.0031 \\
(-3.86)^{* * *}\end{array}$ & $\begin{array}{l}-0.0023 \\
(-3.84)^{* * *}\end{array}$ \\
\hline Average adjusted $\mathrm{R}^{2}$ & 0.1647 & 0.1401 & 0.1856 & 0.1276 \\
\hline \multicolumn{5}{|l|}{ Eq. (6): } \\
\hline APT7Y & $\begin{array}{c}-0.0004 \\
(-0.56)\end{array}$ & $\begin{array}{c}-0.0013 \\
(-1.41)\end{array}$ & $\begin{array}{l}0.0008 \\
(0.87)\end{array}$ & $\begin{array}{c}-0.0002 \\
(-0.39)\end{array}$ \\
\hline APTX7Y & $\begin{array}{l}-0.0017 \\
(-2.42)^{* *}\end{array}$ & $\begin{array}{l}-0.0014 \\
(-1.79)^{*}\end{array}$ & $\begin{array}{l}-0.0060 \\
(-1.89)^{*}\end{array}$ & $\begin{array}{l}-0.0051 \\
(-2.47)^{* *}\end{array}$ \\
\hline Average adjusted $\mathrm{R}^{2}$ & 0.1637 & 0.1336 & 0.1855 & 0.1279 \\
\hline
\end{tabular}

Notes:

APT1 = Length of tenure for the audit partner with longest tenure, where each partner's tenure equals the number of consecutive years that the company has retained the audit partner

APT2 = Number of consecutive years that the company has retained the same two audit partners

$A P T 5 Y=\min (A P T, 5), A P T=A P T 1$ or $A P T 2$

$A P T X 5 Y=A P T-A P T 5 Y, A P T=A P T 1$ or $A P T 2$

$A P T 7 Y=\min (A P T, 7), A P T=A P T 1$ or $A P T 2$

$A P T X 7 Y=A P T-A P T 7 Y, A P T=A P T 1$ or $A P T 2$

$D A=$ Discretionary accruals, as described in Figure 1

$P M D A=$ Performance-matched discretionary accruals, as described in Figure 1

BIG5 $=1$ if the company's audit firm is one of the Big-5 audit firms; $=0$ otherwise

$A G E \quad=$ Number of years since the company was established

SIZE = Natural logarithm of book value of total assets in billion dollars

$L E V \quad=$ Total debt $/$ Total assets at year-end 
GROW $=$ (Total assets at year-end)/(Total assets at the end of previous year $)-1$

$\mathrm{CFO}=$ Cash flow from operations scaled by beginning total assets

The equation is estimated for each year from 1990 to 2001. The reported coefficients are the means of yearly estimates and the $t$-statistics (in parentheses) equal the mean coefficients divided by standard error of yearly estimates. The sample consists of 2,655 $(1,736)$ observations when APT equals APT1 (APT2). The mean coefficient estimates on the intercept, BIG5, AGE, SIZE, LEV, GROW, CFO, and the industry dummy variables are not reported. ${ }^{* *}, *^{* *}$, and * indicate statistical significance at the $1 \%, 5 \%$, and $10 \%$ level, respectively (two-tailed). 
Table 6

\section{Regressions of Absolute Discretionary Accruals on Audit Partner Tenure, Audit Firm Tenure, and Control Variables}

\begin{tabular}{|c|c|c|c|c|}
\hline \multirow[b]{2}{*}{ Variable } & \multicolumn{2}{|c|}{ Panel A: $A P T=A P T 1$} & \multicolumn{2}{|c|}{ Panel B: $A P T=A P T 2$} \\
\hline & Accruals $=D A$ & Accruals $=P M D A$ & Accruals $=D A$ & Accruals $=$ PMDA \\
\hline Intercept & $\begin{array}{c}0.0819 \\
(6.20)^{* * *}\end{array}$ & $\begin{array}{c}0.1073 \\
(5.46)^{* * *}\end{array}$ & $\begin{array}{c}0.0810 \\
(3.93)^{* * *}\end{array}$ & $\begin{array}{c}0.1179 \\
(3.79)^{* * *}\end{array}$ \\
\hline$A P T$ & $\begin{array}{c}-0.0011 \\
(-3.24)^{* * *}\end{array}$ & $\begin{array}{c}-0.0009 \\
(-1.77)\end{array}$ & $\begin{array}{l}-0.0008 \\
(-2.00)^{*}\end{array}$ & $\begin{array}{l}-0.0014 \\
(-4.05)^{* * *}\end{array}$ \\
\hline$A F T$ & $\begin{array}{c}0.0002 \\
(0.60)\end{array}$ & $\begin{array}{c}-0.0005 \\
(-0.66)\end{array}$ & $\begin{array}{c}-0.0008 \\
(-1.26)\end{array}$ & $\begin{array}{c}-0.0004 \\
(-0.57)\end{array}$ \\
\hline BIG5 & $\begin{array}{c}0.0026 \\
(2.56)^{* *}\end{array}$ & $\begin{array}{c}-0.0029 \\
(-0.85)\end{array}$ & $\begin{array}{c}-0.0004 \\
(-0.22)\end{array}$ & $\begin{array}{c}0.0010 \\
(0.28)\end{array}$ \\
\hline$A G E$ & $\begin{array}{l}-0.0006 \\
(-5.28)^{* * *}\end{array}$ & $\begin{array}{l}-0.0003 \\
(-2.12)^{*}\end{array}$ & $\begin{array}{l}-0.0005 \\
(-2.77)^{* *}\end{array}$ & $\begin{array}{c}-0.0003 \\
(-1.56)\end{array}$ \\
\hline SIZE & $\begin{array}{c}-0.0007 \\
(-0.83)\end{array}$ & $\begin{array}{c}-0.0017 \\
(-1.52)\end{array}$ & $\begin{array}{c}-0.0008 \\
(-0.50)\end{array}$ & $\begin{array}{c}-0.0020 \\
(-0.95)\end{array}$ \\
\hline$L E V$ & $\begin{array}{c}0.0014 \\
(0.15)\end{array}$ & $\begin{array}{c}-0.0054 \\
(-0.57)\end{array}$ & $\begin{array}{c}0.0126 \\
(0.89)\end{array}$ & $\begin{array}{c}0.0025 \\
(0.19)\end{array}$ \\
\hline GROW & $\begin{array}{c}0.0258 \\
(3.07)^{* * *}\end{array}$ & $\begin{array}{l}0.0323 \\
(4.13)^{* * *}\end{array}$ & $\begin{array}{c}0.0352 \\
(4.98)^{* * *}\end{array}$ & $\begin{array}{l}0.0393 \\
(4.29)^{* * *}\end{array}$ \\
\hline CFO & $\begin{array}{l}-0.1400 \\
(-4.28)^{* * *}\end{array}$ & $\begin{array}{l}-0.0750 \\
(-2.88)^{* *}\end{array}$ & $\begin{array}{l}-0.1263 \\
(-3.53)^{* * *}\end{array}$ & $\begin{array}{l}-0.0800 \\
(-3.38)^{* * *}\end{array}$ \\
\hline Average adjusted $\mathrm{R}^{2}$ & 0.1626 & 0.1366 & 0.1826 & 0.1327 \\
\hline
\end{tabular}

Notes:

APT1 = Length of tenure for the audit partner with longest tenure, where each partner's tenure equals the number of consecutive years that the company has retained the audit partner

$A P T 2=$ Number of consecutive years that the company has retained the same two audit partners

$A F T=$ Number of consecutive years that the company has retained the audit firm

$D A=$ Discretionary accruals, as described in Figure 1

$P M D A=$ Performance-matched discretionary accruals, as described in Figure 1

BIG5 = 1 if the company's audit firm is one of the Big-5 audit firms; $=0$ otherwise

$A G E=$ Number of years since the company was established

SIZE = Natural logarithm of book value of total assets in billion dollars

$L E V=$ Total debt $/$ Total assets at year-end

GROW $=$ (Total assets at year-end $) /($ Total assets at the end of previous year $)-1$

$\mathrm{CFO}=$ Cash flow from operations scaled by beginning total assets 
The equation is estimated for each year from 1990 to 2001. The reported coefficients are the means of yearly estimates and the $t$-statistics (in parentheses) equal the mean coefficients divided by standard error of yearly estimates. The sample consists of 2,655 $(1,736)$ observations when APT equals APT1 (APT2). The mean coefficient estimates on the industry dummy variables are not reported. ${ }^{* * *}, * *$, and * indicate statistical significance at the $1 \%, 5 \%$, and $10 \%$ level, respectively (two-tailed). 
Table 7

Regressions of Absolute Discretionary Accruals on Audit Partner Tenure for Big-5 Auditors' Clients, Audit Partner Tenure for Non-Big-5 Auditors' Clients, and Control Variables

$$
\begin{aligned}
\mid \text { Accruals } \mid= & \beta_{0}+\beta_{1} A P T^{*} B I G 5+\beta_{2} A P T^{*} \text { NonBIG5 }+\beta_{3} B I G 5+\beta_{4} A G E+\beta_{5} \text { SIZE }+\beta_{6} L E V \\
& +\beta_{7} G R O W+\beta_{8} C F O+\gamma \cdot \text { Industry }+\varepsilon
\end{aligned}
$$

\begin{tabular}{lccccc}
\hline \multirow{2}{*}{ Variable } & \multicolumn{2}{c}{ Panel A: APT $=$ APT1 } & & \multicolumn{2}{c}{ Panel B: APT = APT2 } \\
\cline { 2 - 3 } \cline { 5 - 6 } Intercept & Accruals $=D A$ & Accruals $=$ PMDA & & Accruals $=$ DA & Accruals $=$ PMDA \\
APT* BIG5 & 0.0738 & 0.0837 & & 0.0797 & 0.0964 \\
& $(13.37)^{* * *}$ & $(9.46)^{* * *}$ & & $(8.62)^{* * *}$ & $(10.19)^{* * *}$ \\
APT*NonBIG5 & -0.0009 & -0.0014 & & -0.0004 & -0.0012 \\
& $(-1.95)^{*}$ & $(-2.26)^{* *}$ & & $(-1.13)$ & $(-2.60)^{* * *}$ \\
BIG5 & -0.0010 & -0.0011 & & -0.0031 & -0.0023 \\
& $(-1.60)$ & $(-1.49)$ & & $(-3.77)^{* * *}$ & $(-2.32)^{* *}$ \\
AGE & 0.0018 & -0.0023 & & -0.0154 & -0.0061 \\
& $(0.30)$ & $(-0.28)$ & & $(-4.18)^{* * *}$ & $(-1.03)$ \\
SIZE & -0.0006 & -0.0003 & & -0.0005 & -0.0003 \\
& $(-5.74)^{* * *}$ & $(-2.29)^{* *}$ & & $(-3.18)^{* * *}$ & $(-1.75)$ \\
LEV & -0.0005 & -0.0019 & & -0.0009 & -0.0021 \\
& $(-0.67)$ & $(-1.52)$ & & $(-0.59)$ & $(-1.02)$ \\
GROW & 0.0012 & -0.0044 & & 0.0097 & -0.0008 \\
& $(0.13)$ & $(-0.44)$ & & $(0.67)$ & $(-0.06)$ \\
CFO & 0.0262 & 0.0325 & & 0.0360 & 0.0394 \\
& $(3.12)^{* * *}$ & $(4.05)^{* * *}$ & & $(4.88)^{* * *}$ & $(4.28)^{* * *}$ \\
Average adjusted $\mathrm{R}^{2}$ & -0.1381 & -0.0724 & & -0.1265 & -0.0817 \\
& $(-4.26)^{* * * *}$ & $(-2.83)^{* *}$ & & $(-3.57)^{* * *}$ & $(-3.43)^{* * *}$ \\
& 0.1630 & 0.1339 & 0.1787 & 0.1293 \\
\hline
\end{tabular}

Notes:

APT1 = Length of tenure for the audit partner with longest tenure, where each partner's tenure equals the number of consecutive years that the company has retained the audit partner

APT2 = Number of consecutive years that the company has retained the same two audit partners

$D A=$ Discretionary accruals, as described in Figure 1

$P M D A=$ Performance-matched discretionary accruals, as described in Figure 1

BIG5 = 1 if the company's audit firm is one of the Big-5 audit firms; $=0$ otherwise

NonBIG5 $=1$ if the company's audit firm is not one of the Big- 5 audit firms; $=0$ otherwise

$A G E \quad=$ Number of years since the company was established

SIZE = Natural logarithm of book value of total assets in billion dollars

$L E V \quad=$ Total debt $/$ Total assets at year-end

GROW $=$ (Total assets at year-end)/(Total assets at the end of previous year $)-1$

$\mathrm{CFO}=$ Cash flow from operations scaled by beginning total assets 
The equation is estimated for each year from 1990 to 2001. The reported coefficients are the means of yearly estimates and the $t$-statistics (in parentheses) equal the mean coefficients divided by standard error of yearly estimates. The sample consists of 2,655 $(1,736)$ observations when APT equals APT1 (APT2). The mean coefficient estimates on the industry dummy variables are not reported. $* * *, * *$, and * indicate statistical significance at the $1 \%, 5 \%$, and 10\% level, respectively (two-tailed). 